DOI: 10.17707/AgricultForest.61.2.07

\author{
Imer RUSINOVCI, Sali ALIU \\ Shukri FETAHU, Petr SEDLAK, Dukagjin ZEKA ${ }^{I}$
}

\title{
THE MINERAL COMPOSITION IN SOME LOCAL POTATO (Solanum tuberosum L.) POPULATIONS GROWING IN KOSOVO
}

\section{SUMMARY}

The mineral composition of potato tubers are variable and depend on genotypes, soil fertility, agro-technology applied and climatic conditions. Aim of this paper was research of 22 local potato populations (LPP's) in terms of diversity of microelements ( $\mathrm{Zn}, \mathrm{Cu}$, and $\mathrm{Fe}$ ) and macro-elements $(\mathrm{Ca}, \mathrm{Na}, \mathrm{K}$, and $\mathrm{Mg}$ ) contents. The randomized block design experiment (RBDE) with three replications was carried out. The genetic relative variability between LPP for the mineral content were with significant differences at both levels of probability $\mathrm{LSD}=0.05$ and $\mathrm{LSD}=0.01$. The LPP's involved in this research generally showed high diversity in terms of mineral content.

Keywords: potato, populations, micro, and macro elements, variability

\section{INTRODUCTION}

Potato (Solanum tuberosum L.) is one of most important crop for human nutrition, food industry, and agriculture like for cultivation surface also for high production ability. In many countries potato is also used as animal feed. According to statistics, the global production of potatoes in 2010 was 325 million tons, with $52 \%$ of the production is used for the purpose of consumption, $33.5 \%$ for animal feed, $11 \%$ seed production, $2.8 \%$ for the manufacture of starch and $0.7 \%$ for the production of alcohol. Among the biggest producers are: China, Russia, Ukraine, India, Poland, Belarus (FAO, 2012). Kosovo has an area of $10.887 \mathrm{~km}^{2}$ or 1.1 million ha, about 430.00 ha forested or $39.1 \%$ and 577.000 ha are agriculture land or 52\% (Rusinovci et al., 2014)

In Kosovo potato is cultivated in about 10,000 ha with an average low production 10-12 t.ha ${ }^{-1}$ and represents one of the main agricultural crops as agronomic importance, physiological and manufacturing, as well as nutrition to the population. To determinate the genotype structure the main factor are include genetically, agro ecological and agro technical factors (Jovovic et al., 2002). Plant genetic resources are considered to be priceless and the preservation of biological diversity a matter of the long term sustainability of human life (Aliu et

\footnotetext{
1 Sali Aliu, (corresponding author: sali.aliu@uni-pr.edu), Imer Rusinovci, Shukri Fetahu, University of Prishtina, Faculty of Agriculture and Veterinary, Department of Crop Science, Bill "Bill Clinton" n.n. Prishtinë 10000, Kosovo; Petr Sedlák, Dukagjin Zeka: Czech University of Life Sciences Prague, Faculty of Agrobiology, Food and Natural Resources, Department of Genetics and Breeding, Kamýcká 129, Prague 6-Suchdol 165 21, Czech Republic.

Notes: The authors declare that they have no conflicts of interest. Authorship Form signed online.
} 
al., 2013). Plant genetic resources are a reservoir of genetic diversity and a valuable material for creating new cultivars (Jovovic et al., 2012). Chemical composition of potato tubers varies as far as each lengthwise and crosswise section of each individual tuber is concerned. The crude protein $(\mathrm{N} \times$ 6.25) represents in tubers approximately $2 \%$ of a fresh weight that creates approximately $10 \%$ of dry matter. However, the crude protein content ranges significantly in dependence on genotype and growing conditions (Bartova et al., 2009).

Potato tubers are rich in chemicals, which don't have the same distribution. Most of them are found in large concentrations in the tubers skin (cortex), and less on their inside, Wszelaki et al., 2005). The concentration of dry matter, ash and other chemical components of tubers are highly influenced by the characteristics of the cultivars (Rusinovci et al., 2012). Mineral substances cannot be synthesized by plants, they acquired from dissolves in soil through the roots of plants. Although the tubers have associated rootlets with the possible exception of $\mathrm{Ca}$, these rootlets in small quantities supply tubers with minerals (Karenlampi and White, 2009). Several studies point out the fact that the potato is an important route of transfer of minerals from the ground up to human consumption (Reid et al., 2003; Dugo et al., 2004). The concentration of mineral substances in potato tubers varies greatly among cultivars, soil type and land cultivation (Lewis et al., 2011). In general, the total amount of mineral substances ranges between 0.44-1.90 percent depending on the cultivar.

Macro-elements $(\mathrm{Ca}, \mathrm{Na}, \mathrm{K}$, and $\mathrm{Mg}$ ) are vital to human health. Calcium (Ca) plays a key role in hardening of the skeleton and is involved in neuromuscular function, blood coagulation and many metabolic processes (Frossard et al., 2000). Deficit of Ca can result in spasm and short pain of muscles and osteoporosis (Andre et al., 2007). Dietary reference intakes (DRIs), FAO/WHO, for Calcium are estimated to be $1000 \mathrm{mg}^{\text {day }}{ }^{-1}$ for adults (Anonymous, 2002). Micro-elements $(\mathrm{Zn}, \mathrm{Cu}$, and $\mathrm{Fe}$ ) although participate in minor amounts in the composition of plants and are important for their development and growth. Zinc ( $\mathrm{Zn}$ ) plays a role in the formation of growth hormones (auxins), the formation of the fruit, promotes ripening, helps the synthesis of proteins, etc. Copper $(\mathrm{Cu})$ helps as activators of enzymes, plays great function in photosynthesis and reproduction phase, contributes to increased sugar content, etc. Whereas, Iron (Fe) supports the formation of chlorophyll, enzymes, contributes to the operating mechanism of the cell respiration system, and has a functional contribution in reactions involving cell division and development. Daily consumption in food of $\mathrm{Cu}$ and $\mathrm{Zn}$ was investigated by Blanusa and Jorhem (1990) (replace reference with a newer reference because, according to Thomson Reuters, this one is quite old) and it is estimated to be 8.1 $\mu \mathrm{g} /$ person/day for $\mathrm{Zn}$ and $0.6 \mu \mathrm{g} /$ person/day for $\mathrm{Cu}$.

The purpose of the paper is based on research of the impact of local populations in the content of mineral substances in the tubers of this culture. 


\section{MATERIAL AND METHODS}

The research included 22 accessions of potato, collected from different localities (Table 1) during 2011 expeditions. These accessions were cultivated next two years in experimental farm of Faculty of Agriculture and Veterinary in Prishtina. Experimental farm is situated at latitude of $42^{\circ} 38^{\prime} \mathrm{N}$, longitude of $21^{\circ}$ $08^{\prime} \mathrm{E}$ and an altitude of 560 meters above sea level.

Table 1. Geographically Origin of Local potato populations

\begin{tabular}{|c|c|c|c|c|c|}
\hline Order & $\begin{array}{c}\text { Accession } \\
\text { Code }\end{array}$ & Longitude & Latitude & Altitude & Location \\
\hline 1. & FAGB-01 & $21^{\circ} 06^{\prime} 25^{\prime \prime}$ & $42^{\circ} 22^{\prime} 48^{\prime \prime}$ & 611 & Balaj - Ferizaj \\
\hline 2. & FAGB-02 & $21^{\circ} 18^{\prime} 64^{\prime \prime}$ & $42^{\circ} 16^{\prime} 95^{\prime \prime}$ & 547 & Kaçanik i vjetër \\
\hline 3. & FAGB-03 & $21^{\circ} 18^{\prime} 007^{\prime \prime}$ & $42^{\circ} 17^{\prime} 09^{\prime \prime}$ & 564 & Kaçanik i vjetër \\
\hline 4. & FAGB-04 & $21^{\circ} 10^{\prime} 56^{\prime \prime}$ & $42^{\circ} 15^{\prime \prime} 72^{\prime \prime}$ & 511 & Prushaj - Kaçanik \\
\hline 5. & FAGB-05 & $21^{\circ} 23 ' 33^{\prime \prime}$ & $42^{\circ} 16^{\prime} 24^{\prime \prime}$ & 881 & Dobëllde - Viti \\
\hline 6. & FAGB-06 & $21^{\circ} 20^{\prime} 96^{\prime \prime}$ & $42^{\circ} 15^{\prime} 55^{\prime \prime}$ & 1033 & Dobëllde - Viti \\
\hline 7. & FAGB-07 & $21^{\circ} 23^{\prime} 99^{\prime \prime}$ & $42^{\circ} 15 ' 57^{\prime \prime}$ & 1019 & Dobeëlde - Viti \\
\hline 8. & FAGB-07A & $21^{\circ} 23^{\prime} 99^{\prime \prime}$ & $42^{\circ} 15^{\prime} 57^{\prime \prime}$ & 1019 & Dobëllde - Viti \\
\hline 9. & FAGB-08 & $21^{\circ} 32^{\prime} 82^{\prime \prime}$ & $42^{\circ} 34 ' 21^{\prime \prime}$ & 625 & Rubovc - Kamenicë \\
\hline 10. & FAGB-09 & $21^{\circ} 32^{\prime} 82^{\prime \prime}$ & $42^{\circ} 34^{\prime} 21^{\prime \prime}$ & 625 & Rubovc - Kamenicë \\
\hline 11. & FAGB-10 & $21^{\circ} 30^{\prime} 40^{\prime \prime}$ & $42^{\circ} 34^{\prime} 14^{\prime \prime}$ & 867 & Busavatë - Kamenicë \\
\hline 12. & FAGB-11 & $21^{\circ} 28^{\prime} 82^{\prime \prime}$ & $42^{\circ} 22^{\prime \prime} 76^{\prime \prime}$ & 502 & Zheger - Gjilan \\
\hline 13. & FAGB-12 & $20^{\circ} 30^{\prime} 53^{\prime \prime}$ & $42^{\circ} 46^{\prime \prime} 71^{\prime \prime}$ & 494 & Dushkajë - Burim \\
\hline 14. & FAGB-13 & $20^{\circ} 26^{\prime} 91^{\prime \prime}$ & $42^{\circ} 46^{\prime} 66^{\prime \prime}$ & 489 & Cercë - Burim \\
\hline 15. & FAGB-14 & $20^{\circ} 27^{\prime} 05^{\prime \prime}$ & $42^{\circ} 46^{\prime} 62^{\prime \prime}$ & 482 & Cercë - Burim \\
\hline 16. & FAGB-15 & $20^{\circ} 27^{\prime} 06^{\prime \prime}$ & $42^{\circ} 46^{\prime} 58^{\prime \prime}$ & 479 & Cercë - Burim \\
\hline 17. & FAGB-16 & $20^{\circ} 28^{\prime} 58^{\prime \prime}$ & $42^{\circ} 43^{\prime} 19^{\prime \prime}$ & 441 & Gurakoc - Burim \\
\hline 18. & FAGB-17 & $21^{\circ} 03 ' 28^{\prime \prime}$ & $42^{\circ} 49^{\prime} 90^{\prime \prime}$ & 600 & Samadraxhë - Vushtrri \\
\hline 19. & FAGB-18 & $21^{\circ} 08^{\prime} 56^{\prime \prime}$ & $42^{\circ} 19^{\prime} 42$ & 593 & Greme - Ferizaj \\
\hline 20. & FAGB-19 & $21^{\circ} 09^{\prime} 38^{\prime \prime}$ & $42^{\circ} 19^{\prime} 03^{\prime \prime}$ & 559 & Omuraj - Ferizaj \\
\hline 21. & FAGB-20 & $21^{\circ} 09^{\prime} 52^{\prime \prime}$ & $42^{\circ} 19^{\prime} 54^{\prime \prime}$ & 551 & Omuraj - Ferizaj \\
\hline 22. & FAGB-21 & $21^{\circ} 13^{\prime} 12^{\prime \prime}$ & $42024^{\prime} 48^{\prime \prime}$ & 679 & Prishtinë \\
\hline
\end{tabular}

The randomized block design experiment with three replications was carried out. For each replication plot by 20 plants $(70 \times 30 \mathrm{~cm})$ were cultivated. Weeds elimination was done by mechanical and chemical way. Harvest was realized at the end of July. After harvesting, according to the standard methodology, from each accession in each experimental field samples of $5 \mathrm{~kg}$ tubers for chemical contents analysis were taken. Each sample was washed in deionized water to clean soil particles, briefly air-dried and then peeled. Tuber flesh was used for chemical analyses. Mineral composition, were determined after six 
hour sample combustion at $700^{\circ} \mathrm{C}$, then the samples were dissolved with $\mathrm{HCl}$ in the ratio 1:4. Determination of chemical elements contents in samples was done by atomic absorption spectroscopy (AAS). Data were analyzed using ANOVA procedure with the statistical software SAS 9.1 En, and Duncan's test for comparison of means was applied.

\section{RESULTS AND DISCUSSION}

Besides productivity output, quality remains a key element in the use of agricultural crops in general.

Table 2. Average mean of mineral elements (micro and macro-elements) $\mathrm{mg} \mathrm{kg}^{-1}$

\begin{tabular}{|c|c|c|c|c|c|c|c|}
\hline $\begin{array}{c}\text { Accession } \\
\text { Code }\end{array}$ & $\mathrm{Ca}$ & $\mathrm{Na}$ & $\mathrm{K}$ & $\mathrm{Mg}$ & $\mathrm{Zn}$ & $\mathrm{Cu}$ & $\mathrm{Fe}$ \\
\hline FAGB-01 & $64,76^{\mathrm{GHIJ}}$ & $27,05^{\mathrm{ABCD}}$ & $2884,80^{\mathrm{ABC}}$ & $218,76^{\mathrm{EF}}$ & $4,75^{\mathrm{ABCDE}}$ & $3,55^{\mathrm{BCDE}}$ & $9,85^{\mathrm{BC}}$ \\
\hline FAGB-02 & $49,78^{\mathrm{J}}$ & $11,40^{\mathrm{F}}$ & $3144,15^{\mathrm{AB}}$ & $207,94^{\mathrm{FG}}$ & $3,90^{\mathrm{CDEF}}$ & $2,65^{\mathrm{CDEF}}$ & $8,25^{\mathrm{BCDEF}}$ \\
\hline FAGB-03 & $77,39^{\text {EFGHIJ }}$ & $29,30^{\mathrm{ABC}}$ & $2456,35^{\mathrm{BCDE}}$ & $183,29^{\mathrm{FG}}$ & $3,95^{\mathrm{BCDEF}}$ & $4,65^{\mathrm{AB}}$ & $18,04^{\mathrm{A}}$ \\
\hline FAGB-04 & $61,52^{\mathrm{HIJ}}$ & $32,55^{\mathrm{AB}}$ & $2438,90^{\mathrm{BCDE}}$ & $195,02^{\mathrm{FG}}$ & $3,15^{\mathrm{EF}}$ & $3,35^{\mathrm{BCDEF}}$ & $7,44^{\text {BCDEFG }}$ \\
\hline FAGB-05 & $55,77^{\mathrm{HIJ}}$ & $12,70^{\mathrm{EF}}$ & $2417,55^{\text {BCDE }}$ & $214,20^{\mathrm{EF}}$ & $5,75^{\mathrm{A}}$ & $2,70^{\mathrm{CDEF}}$ & $8,75^{\mathrm{BCDE}}$ \\
\hline FAGB-06 & $83,76^{\text {EFGHIJ }}$ & $26,70^{\mathrm{ABCD}}$ & $3168,00^{\mathrm{AB}}$ & $213,45^{\mathrm{EF}}$ & $4,60^{\mathrm{ABCDE}}$ & $1,25^{\mathrm{F}}$ & $9,23^{\mathrm{BCD}}$ \\
\hline FAGB-07 & $51,13^{\mathrm{IJ}}$ & $12,30^{\mathrm{EF}}$ & $3078,45^{\mathrm{AB}}$ & $195,81^{\mathrm{FG}}$ & $3,18^{\mathrm{EF}}$ & $1,30^{\mathrm{F}}$ & $4,53^{\mathrm{FG}}$ \\
\hline FAGB-07A & $67,28^{\text {FGHIJ }}$ & $9,10^{\mathrm{F}}$ & $1040,10^{\mathrm{E}}$ & $193,78^{\mathrm{FG}}$ & $3,60^{\mathrm{DEF}}$ & $2,00^{\mathrm{EF}}$ & $5,36^{\text {DEFG }}$ \\
\hline FAGB-08 & $103,15^{\text {DEFGH }}$ & $10,75^{\mathrm{F}}$ & $1509,05^{\mathrm{CDE}}$ & $189,63^{\mathrm{FG}}$ & $4,40^{\mathrm{ABCDE}}$ & $1,90^{\mathrm{EF}}$ & $9,95^{\mathrm{B}}$ \\
\hline FAGB-09 & $62,54^{\mathrm{HIJ}}$ & $9,35^{\mathrm{F}}$ & $1186,10^{\mathrm{DE}}$ & $136,92^{\mathrm{G}}$ & $2,70^{\mathrm{F}}$ & $2,10^{\mathrm{EF}}$ & $6,14^{\text {BCDEFG }}$ \\
\hline FAGB-10 & $99,82^{\text {DEFGHI }}$ & $9,40^{\mathrm{F}}$ & $1123,35^{\mathrm{E}}$ & $363,50^{\mathrm{ABC}}$ & $4,55^{\mathrm{ABCDE}}$ & $3,55^{\mathrm{BCDE}}$ & $4,30^{\mathrm{FG}}$ \\
\hline FAGB-11 & $102,27^{\text {DEFGH }}$ & $22,25^{\mathrm{BCDE}}$ & $3597,65^{\mathrm{AB}}$ & $300,35^{\text {BCD }}$ & $5,50^{\mathrm{AB}}$ & $4,40^{\mathrm{ABCD}}$ & $3,37^{\mathrm{G}}$ \\
\hline FAGB-12 & $74,22^{\text {EFGHIJ }}$ & $17,10^{\mathrm{DEF}}$ & $3363,10^{\mathrm{AB}}$ & $368,65^{\mathrm{AB}}$ & $4,85^{\mathrm{ABCD}}$ & $5,40^{\mathrm{AB}}$ & $6,00^{\text {BCDEFG }}$ \\
\hline FAGB-13 & $212,94^{\mathrm{A}}$ & $13,35^{\mathrm{EF}}$ & $2594,00^{\mathrm{BCD}}$ & $368,95^{\mathrm{AB}}$ & $4,05^{\mathrm{BCDEF}}$ & $6,20^{\mathrm{A}}$ & $5,09^{\mathrm{DEFG}}$ \\
\hline FAGB-14 & $152,95^{\mathrm{BC}}$ & $28,85^{\mathrm{ABC}}$ & $3170,95^{\mathrm{AB}}$ & $299,95^{\text {BCD }}$ & $4,05^{\mathrm{BCDEF}}$ & $1,40^{\mathrm{F}}$ & $3,55^{\mathrm{G}}$ \\
\hline FAGB-15 & $68,02^{\text {FGHIJ }}$ & $18,75^{\mathrm{CDEF}}$ & $2864,30^{\mathrm{ABC}}$ & $418,80^{\mathrm{A}}$ & $4,35^{\mathrm{ABCDEF}}$ & $3,55^{\mathrm{BCDE}}$ & $5,70^{\mathrm{CDEFG}}$ \\
\hline FAGB-16 & $114,15^{\text {CDEFG }}$ & $11,95^{\mathrm{EF}}$ & $3326,35^{\mathrm{AB}}$ & $422,95^{\mathrm{A}}$ & $3,80^{\mathrm{CDEF}}$ & $2,45^{\mathrm{DEF}}$ & $5,30^{\mathrm{DEFG}}$ \\
\hline FAGB-17 & $117,80^{\mathrm{CDE}}$ & $12,30^{\mathrm{EF}}$ & $4161,60^{\mathrm{A}}$ & $233,10^{\mathrm{DEF}}$ & $4,75^{\mathrm{ABCDE}}$ & $1,75^{\mathrm{F}}$ & $6,00^{\text {BCDEFG }}$ \\
\hline FAGB-18 & $141,89^{\mathrm{CD}}$ & $11,40^{\mathrm{F}}$ & $2860,80^{\mathrm{ABC}}$ & $365,90^{\mathrm{AB}}$ & $5,20^{\mathrm{ABCD}}$ & $3,00^{\mathrm{CDEF}}$ & $5,34^{\text {DEFG }}$ \\
\hline FAGB-19 & $134,45^{\mathrm{CD}}$ & $16,65^{\mathrm{DEF}}$ & $3401,40^{\mathrm{AB}}$ & $373,60^{\mathrm{AB}}$ & $5,25^{\mathrm{ABCD}}$ & $6,45^{\mathrm{A}}$ & $7,10^{\text {BCDEFG }}$ \\
\hline FAGB-20 & $191,84^{\mathrm{AB}}$ & $15,05^{\mathrm{EF}}$ & $2678,55^{\mathrm{BC}}$ & $287,95^{\mathrm{CDE}}$ & $5,40^{\mathrm{ABC}}$ & $5,35^{\mathrm{AB}}$ & $4,80^{\mathrm{EFG}}$ \\
\hline FAGB-21 & $114,33^{\mathrm{CDEF}}$ & $34,00^{\mathrm{A}}$ & $3811,30^{\mathrm{AB}}$ & $417,95^{\mathrm{A}}$ & $4,65^{\mathrm{ABCDE}}$ & $4,40^{\mathrm{ABCD}}$ & $7,80^{\mathrm{BCDEF}}$ \\
\hline Mean & 100,08 & 17,83 & 2739,85 & 280,47 & 4,38 & 3,33 & 6,90 \\
\hline $\operatorname{LSD}_{0.05}$ & 36,45 & 7,95 & 1045,7 & 55,95 & 1,23 & 1,58 & 3,09 \\
\hline 0.01 & 49,54 & 10,80 & 1421,4 & 76,04 & 1,67 & 2,14 & 4,20 \\
\hline
\end{tabular}

* Mean values of the same category followed by different letters are significant at $p \leq 0.01$ level. 
Average amount of $\mathrm{Ca}$ in tubers in our experimental research was 100.08 $m g \mathrm{~kg}^{-1}$ (Table 2). The extreme values of the accessions were found in accession FABG-13 with average value $+112.86 \mathrm{mg} \mathrm{kg}^{-1}$ or expressed in relative value $112.77 \%$, while lowest value, compared to the experimental average, was found in accession FABG-02 $\left(-50.30 \mathrm{mg} \mathrm{kg}^{-1}\right)$ or $-50.26 \%$ of relative genetic value.

Genetic relative variability between accessions for the amount of $\mathrm{Ca}$ in the tuber was $163.04 \%$ and the results are significant at both levels of probability (LSD ${ }_{\mathrm{p} \leq 0.05}$ and LSD ${ }_{\mathrm{p} \leq 0.01}$ ) (the details are presented in Table 2 and Graph 1 respectively). Rusinovci et al. (2012) found lower value of $\mathrm{Ca}$ in some commercial variety cultivated in Kosovo.
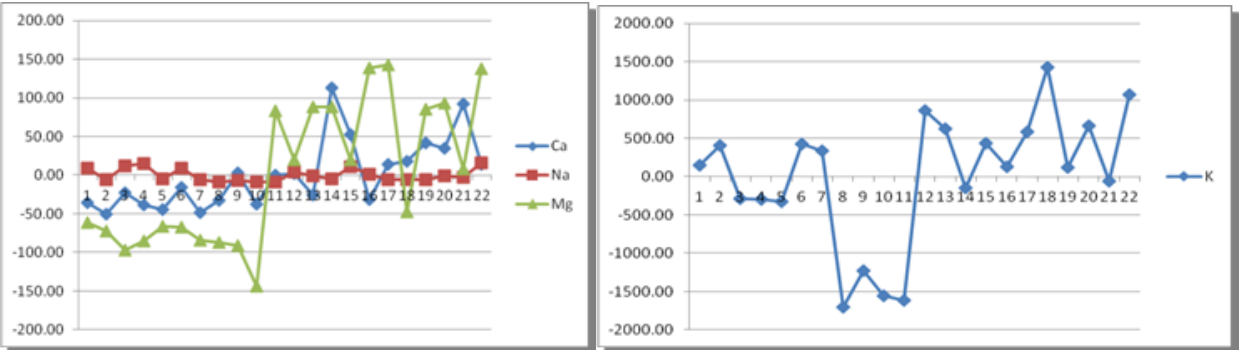

Graph 1. Variability of mean values of macro-elements

( $\mathrm{Ca}, \mathrm{Na}, \mathrm{Mg} \& \mathrm{~K}$ ) compare to the general average value.

The accession FAGB-21 obtained the highest amount of sodium (Na) and magnesium $(\mathrm{Mg})$ with average value +16.17 and $+142.14 \mathrm{mg} \mathrm{kg}^{-1}$, or expressed in genetic relative value $90.69 \%$ and $50.80 \%$ respectively, over experimental average of respective parameters. However, lowest concentration of Na reviled in accession FAGB-07A with value $-87.3 \mathrm{mg} \mathrm{kg}^{-1}$ or $-48.98 \%$ according to the relative genetic variability, whereas accession FABG-09 obtained lowest concentration of $\mathrm{Mg}\left(-143.56 \mathrm{mg} \mathrm{kg}^{-1}\right)$ or $-51.18 \%$ of genetic relative variability. General genetic variability, compare between extreme values of experiment, to the $\mathrm{Na}$ was $139.66 \%$ respectively $101.98 \%$ to the $\mathrm{Mg}$, furthermore results were statistically highly significant (LSD $\leq \leq 0.05$ and LSD $\mathrm{p} \leq 0.01$ ) and presented in Table 2 and Graph 1. Researched accessions had lower concentration of $\mathrm{Na}$ and higher concentration of $\mathrm{Mg}$ compare to modern varieties (Rusinovci et al., 2012). Potassium $(\mathrm{K})$ is vital in plant processes, even it is not part of any of their chemical structure, plays many regulating roles in development. Potassium plays a vital role in stoma activity, photosynthesis, sugar transport, transport of nutrient and water, protein and starch synthesis, activation of enzymes and production quality. The results of our research on local accessions for amount of $\mathrm{K}$ in the potato tubers were different (Table 2, Graph 1). The highest concentration was found in accession FAGB-17, which compared with the experimental average value was higher $+857.80 \mathrm{mg} \mathrm{kg}^{-1}$ or $31.31 \%$ of relative genetic variability, whereas the lowest concentration was found in accession FAGB-07A (-1699.75 $m g \mathrm{~kg}^{-1}$ ) or $-62.04 \%$ of genetic relative variability. The relative genetic variability 
between extreme values of the potassium was 93.35\%. Results of the concentration of $\mathrm{K}$ in this study were higher compared with previous data (Rusinovci et al., 2012).

The amount of micro-minerals in our research was different, depending on the accession. Experimental average value of the amount of $\mathrm{Zn}$ was $438 \mathrm{mg} \mathrm{kg}^{-1}$ (Table 2). Accession FAGB-05 realized higher value $+1.37 \mathrm{mg} \mathrm{kg}^{-1}$, while the lowest value performed accession FAGB-09 (-1.68 $\left.\mathrm{mg} \mathrm{kg}^{-1}\right)$, compared with the experiment average value (Graph 2). Relative genetic variability of extreme values of $\mathrm{Zn}$, compared with experimental average was $38.37 \%$ and $-31.25 \%$ respectively, while the relative variability between them was $69.62 \%$ in total.

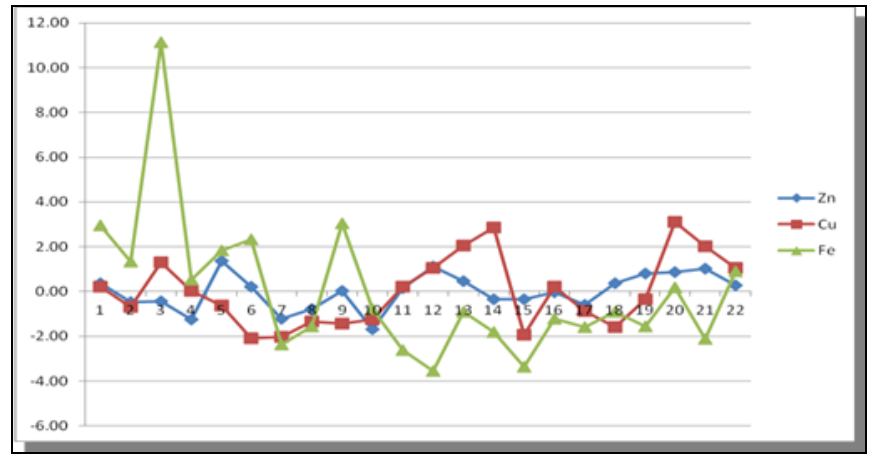

Graph 2. Variability of mean values of micro-elements

( $\mathrm{Zn}, \mathrm{Cu} \& \mathrm{Fe}$ ) compare to the general average value.

The amount of $\mathrm{Cu}$, compared with the experimental average differs from +3.12 $\mathrm{mg} \mathrm{kg}^{-1}$ in accession FAGB-19 to $-2.08 \mathrm{mg} \mathrm{kg}^{-1}$ that was obtained in accession FAGB-06 (Graph 2). Moreover, extreme values of relative genetic variability for $\mathrm{Cu}$ companied to experimental average are $93.46 \%$ and $62.51 \%$, while the value of the general relative genetic variability is $155.69 \%$. The higher value of Fe concentration is determined to accession FAGB-03 $18.4 \mathrm{mg} \mathrm{kg}^{-1}$ or $+11.14 \mathrm{mg} \mathrm{kg}^{-1}$ compared with the experimental average (Graph 2) or expressed in terms of relative genetic variability was $161.34 \%$, whereas accession FAGB11 realized lowest value $-3.53 \mathrm{mg} \mathrm{kg}^{-1}$ compared to the experimental average or according to the relative value of genetic variability was $-51.18 \%$, whereas the overall variability of genetic relative of tested accession was $212.52 \%$. Rusinovci et al. (2012) found much lower values of $\mathrm{Fe}$ concentration in commercial varieties. This research found significant results in micro-elements at both levels of probability LSD $\mathrm{p} \leq 0.05$ and LSD $\mathrm{p} \leq 0.01$ (Table 2).

\section{CONCLUSIONS}

Based on the results obtained from the research it can be concluded that the potato genetic resources involved in this research generally showed high diversity in terms of content of minerals. Higher amounts of most minerals compared to commercial cultivars indicate the quality of indigenous genetic 
resources which have to conserve in national gene bank of plant genetic resources and can be a good basis for breeding programs also. An integrated research of these resources needed.

\section{ACKNOWLEDGEMENTS}

Sincere thanks goes to the farmers, and National Gene Bank of PGR in Kosovo for providing of plant material (accessions).

\section{REFERENCES}

Aliu, S. Rusinovci, I. Fetahu,Sh. Bislimi, K. (2013): Morpho-physiological Traits and Mineral Composition on Local Maize Population Growing in AgroEcological Conditions in Kosova.Notulae Scientia Biologica, 5(2):232-237.

Andre, C. M. Ghislain, M. Bertin, P. Qufir, M. Herrera, M. D. R. Hoffmann, L. Hausman, J. F. O. Larondelle, \& Y. Evers D. (2007): Andean potato cultivars (Solanum tuberosum L.) as a source of antioxidant and mineral micronutrients. Journal of Agricultuar and Food Chemistry., 55: 366-378.

Anonymous. (2002): Food and Agriculture Organization/World Health Organization (FAO/WHO). Human vitamin and mineral requirements. Report of a joint FAO/WHO expert consultation.

Blanusa, M. \& Jorhem, L. (1991): Dietary intake of some essential elements in Sweden and Yugoslavia. In: Momčilović B, (eds). Seventh International Symposium on Trace Elements in Man and Animals (TEMA-7); 20-25 May 1990; Dubrovnik, Croatia., 13: 8-10.

Bartova V., Barta J, Divis J., Svajner J., Peterka J.(2009): Crude protein content in tubers of starch processing potatocultivars in dependence on different agro-ecological conditions.Central European Agriculture. Volume 10. No. 1 (57-66)

Dugo, G. La Pera, L. Lo Turco, V. Giuffrida, D. \& Restuccia, S. (2004): Determination of copper, zinc, selenium, lead and cadmium in potatoes (Solanum tuberosum L.) using potentiometric stripping methods. Food Additives \& Contaminants., 21: $649-657$.

FAO. (2012): http://www.fao.org/corp/statistics/en/ Food and Agriculture Organization of the United Nations (FAO). Rome, Italy.

Frossard, E. Bucher, M. Machler, F. Mozafar, A. \& Hurrell, L. (2000): Potential for increasing the content and bioavailability of $\mathrm{Fe}, \mathrm{Zn}$ and $\mathrm{Ca}$ in plants for human nutrition. Journal of the Science of Food and Agriculture., 80: 861-879.

Karenlampi, S. O. \& White, P. J. (2009): Potato proteins, lipids, and minerals. In: Singh, J. \& Kaur, L. (eds.) Advanced In Potato Biochemistry, Elsevier Academic Publishers, USA, pp. 99-125.

Jovovic Z, Cizmovic M, Lazović B, MarasV, Božović D, Popovic T, Stesevic D, Velimirovic A. (2012): The state of agricultural plant genetic resources in Montenegro. Agriculture \& Forestry, Vol. 57. Issue 1: 33-50.

Jovovic Z, Spalevic V, Momirovic N. (2002): Agroekoloski uslovi za proizvodnja krumpira na regionu Vrulje (okolina Plevalja). Agriculture \& Forestry, Vol. 48. Issue 3-4: 15-29.

Luis, G. Rubio, C. González-Weller, D. Gutiérrez, A. J. Revert, C. \& Hardisson, A. (2011): Comparative study of the mineral composition of several varieties of potatoes (Solanum tuberosum L.) from different countries cultivated in Canary 
Islands (Spain). International Journal of Food Science \& Technology., 46: 774780.

Reid, R. J. Dunbar, K. R. \& McLaughlin, M. J. (2003): Kadmium loading into potato tubers: the roles of the periderm, xylem and phloem. Plant, Cell \& Environment., 26: 201-206.

Rusinovci,I. Aliu,S. Bytyqi,H. Fetahu,Sh. Thaqi,M.Bardhi,N. Lombnaes,P.(2014):

Grassland management for high forage yield and mineral composition in

Kosova. Agriculture and Forestry, Vol. 60. Issue 2: 59-67

Rusinovci, I. Aliu, S. Fetahu, Sh. Kaçiu, S. Salihu, S. Zeka, D. \& Berisha, D. (2012): Contents of mineral substances in the potato (Solanum tuberosum L.) tubers depending on cultivar and locality in the agro-ecological conditions of Kosovo. Acta Horticulturae., 960:289-292.

Wszelaki, A. L. Delwiche, J. F. Walker, S. D. Liggett, R. E. Scheerens, J. C. \& Kleinhenz M. D. (2005): Sensory quality and mineral and glycoalkaloid concentrations in organically and conventionally grown redskin potatoes (Solanum tuberosum L.). Journal of the Science of Food and Agriculture., 85: 720-726. 